\title{
Facile high-yield synthesis of pure, crystalline $\mathrm{Mg}\left(\mathrm{BH}_{4}\right)_{2}$
}

\author{
Pierino Zanella $^{\mathrm{a}}$, Laura Crociani ${ }^{\mathrm{a}}$, Norberto Masciocchi ${ }^{\mathrm{b}}$ and Giovanni Giunchi ${ }^{\mathrm{c}}$
}

a) CNR-ICIS, Corso Stati Uniti 4, 30127 Padova (Italy)

b) Dipartimento di Scienze Chimiche e Ambientali, Università dell'Insubria, via Valleggio 11, 22100 Como (Italy)

c) EDISON SpA, R\&D Division, Foro Buonaparte 31, 20121 Milano (Italy)

\section{Supporting Information}

Synthesis of $\mathbf{A l}\left(\mathbf{B H}_{4}\right)_{3}$ (in toluene solution): $753 \mathrm{mg}$ of purified $\mathrm{LiBH}_{4}(34.56$ $\mathrm{mmol}$ ) were ground in a mortar and set in a $100 \mathrm{ml}$ bottle, where $50 \mathrm{ml}$ of toluene were added. $1.383 \mathrm{~g}$ of purified $\mathrm{AlCl}_{3}(10.37 \mathrm{mmol})$, ground in a mortar, were added slowly to the $\mathrm{LiBH}_{4}$ - toluene mixture. Further $41 \mathrm{ml}$ of toluene were added to wash carefully the bottle walls. The whole mixture was maintained, under stirring, for 60 hours at ambient temperature. Afterwards, the mixture was filtered and the filtrate was distilled at a pressure of about $10^{-1}$ mbar at $30^{\circ} \mathrm{C}$. ([Al] $=0.095 \mathrm{M}$, yield about $\left.78 \%\right)$. The ${ }^{11} \mathrm{~B}-\mathrm{NMR}$ spectrum of the distillate, $\mathrm{Al}\left(\mathrm{BH}_{4}\right)_{3}$ in toluene solution (shown in Figure 2, left trace), displays a quintuplet centered at $-36.50 \mathrm{ppm}$ with $\mathrm{J}_{\mathrm{B}-\mathrm{H}}=88.8 \mathrm{~Hz}$; these values exactly match those measured on a certified sample of $\mathrm{Al}\left(\mathrm{BH}_{4}\right)_{3}$ (dissolved in toluene), prepared following ref. 7.

Synthesis of $\operatorname{Mg}\left(\mathrm{BH}_{4}\right)_{2}$ through reaction pathway (a): to a $35 \mathrm{ml}$ toluene solution of $\mathrm{Al}\left(\mathrm{BH}_{4}\right)_{3}(0.095 \mathrm{M}, 3.33 \mathrm{mmol})$, mantained at $-78^{\circ} \mathrm{C}, 4.5 \mathrm{ml}$ of $1 \mathrm{M}$ heptane solution of $\mathrm{Mg}(\mathrm{n}-\mathrm{But})_{2}(4.5 \mathrm{mmol})$ were added dropwise. After raising the tempertature to $25{ }^{\circ} \mathrm{C}$, the mixture was stirred for additional 12 hours. Afterwards, the white precipitate was filtered, washed twice with $11 \mathrm{ml}$ of toluene and dried under vacuum. The resulting powder was then inserted in a flask with $25 \mathrm{ml}$ of $\mathrm{n}$-hexane and stirred for 3 hours. After this time, the solid was filtered off and washed twice with $8 \mathrm{ml}$ of $\mathrm{n}$-hexane. The hydrocarbon was evaporated under vacuum, initially at room temperature and, later, at 60 ${ }^{\circ} \mathrm{C}$. Yield $=207 \mathrm{mg}(85 \%)$. The ${ }^{11} \mathrm{~B}-\mathrm{NMR}$ spectrum of the product, dissolved in ethyl 
ether, is reported in Figure 2, middle trace, and shows a quintuplet centered at -42.80 ppm, with $\mathrm{J}_{\mathrm{B}-\mathrm{H}}=83.01 \mathrm{~Hz}$. Elemental analysis: Found $\mathrm{C}=1.59 \%, \mathrm{H}=14.72 \% ; \mathrm{Mg}$ 44.10\%; Calc: $\mathrm{C}=0 \%$; $\mathrm{H}=14.96 \% ; \mathrm{Mg} 45.07 \%$. The solid product has been sealed in a Lindemann capillary, under inert atmosphere, and subjected to X-ray powder diffraction analysis. Its diffractogram is reported in Figure 1a.

Synthesis of $\mathrm{Mg}\left(\mathrm{BH}_{4}\right)_{2}$ through reaction pathway (b): $10 \mathrm{ml}$ of a $1 \mathrm{M}$ heptane solution of $\mathrm{Mg}(\mathrm{n}-\mathrm{But})_{2}(10 \mathrm{mmol})$ were added dropwise to $18 \mathrm{ml}$ of a $2 \mathrm{M}$ toluene solution of $\mathrm{H}_{3} \mathrm{~B} \cdot \mathrm{S}\left(\mathrm{CH}_{3}\right)_{2}(36 \mathrm{mmol})$ and the mixture was stirred for 2 hours at room temperature. After filtering, the precipitate was washed twice with $15 \mathrm{ml}$ of toluene. Afterwards, the precipitate has been vacuum-dried at room temperature (at $10^{-1} \mathrm{mbar}$ for $6 \mathrm{~h}$ ), followed by diffusive vacuum $\left(10^{-5} \mathrm{mbar}\right.$, at $75^{\circ} \mathrm{C}$, for 13 hours $)$. Yield $=502 \mathrm{mg}$ $(93 \%)$. The ${ }^{11} \mathrm{~B}-\mathrm{NMR}$ spectrum of the product dissolved in diethylether is reported in Figure 2 (right trace) and is identical with that of the material preapared through pathway (a). Elemental analysis: Found $\mathrm{C}=1.34 \%, \mathrm{H}=14.11 \%$; $\mathrm{Mg} 44.68 \%$; Calc: $\mathrm{C}=0 \%$; $\mathrm{H}=14.96 \% ; \mathrm{Mg} 45.07 \%$. The solid product has been sealed in a Lindemann capillary, under inert atmosphere, and subjected to X-ray powder diffraction analysis. Its diffractogram is reported in Figure $1 b$.

Materials and methods: $\mathrm{AlCl}_{3}$ (Aldrich) was purified by sublimation. $\mathrm{LiBH}_{4}$ was recrystallized from diethyl ether. Solutions of $\operatorname{Mg}(\operatorname{But})_{2}(1 \mathrm{M})$ in heptane (Aldrich) and $\mathrm{BH}_{3} \cdot \mathrm{SMe}_{2}(2 \mathrm{M})$ in toluene (Aldrich) were used as received. All manipulations were carried out under an oxygen- and moisture-free atmosphere in a MBraun MB 200G-II dry-box with an organic solvents scavenger. $\mathrm{Et}_{2} \mathrm{O}$ and toluene were dried before their use, following standard procedures (D.D. Perrin, W.L.F. Armarego, Purification of Laboratory Chemicals 2nd Edition Pergamon Press, 1980).

${ }^{11} \mathrm{~B}$ NMR spectra were recorded on a Bruker AMX-300 spectrometer, operating at 96.251 MHz, using $\mathrm{BF}_{3} \cdot \mathrm{Et}_{2} \mathrm{O}$ as an external standard. Elemental analyses were performed using a FISON Instruments, mod. EA 1108 CHNS-O. X-ray powder diffraction analyses were conducted on a Bruker AXS D8 Advance powder diffractometer equipped with Goebel mirrors, a position sensitive Lynxeye detector, and a rotatory capillary mounting. $\mathrm{Cu}-\mathrm{K} \alpha$ radiation $(\lambda=1.5418 \AA), \theta: \theta$ mode, $5<2 \theta<105^{\circ}$. 